\title{
MENILAI KINERJA PERUSAHAAN RETAIL TRADE YANG TERDAFTAR DI BURSA EFEK INDONESIA BERBASIS LAPORAN KEUANGAN
}

\author{
Jhon Nasyaroeka \\ STIE Prasetiya Mandiri Lampung \\ e-mail: jhonnasyaroeka@gmail.com
}

\begin{abstract}
As for this study reached is to know the performance of the company retail trade in BEI. The contribution of the time period in the study to provide information will be the performance of the company retail trade useful for the investors. Methods used in this study is the documentation the research using the data collection to see its financial report. This study tries to identify financial statements by looking at the performance of retail trade companies through financial ratios of liquidity ratios, solvency ratios, profitability ratios and activity ratios. The results of this study indicate that the liquidity ratio of financial position of retail trade companies in very good condition. The solvency ratio shows that the ratio of this ratio indicates a decrease caused by the company being financed almost with part of the debt. The provitability ratio that is represented by the ROA indicator shows that the profit margin obtained by the company looks quite good. While the ratio of activity shows that the average company in the retail trade produces good corporate value. However, the results of the resulting sales have not obtained optimal results
\end{abstract}

Keyword: performance, financial ratio, financial report$$
\text { PENDAHULUAN }
$$

Hampir semua perusahaan dalam menjalankan suatu usaha pasti mempunyai tujuan untuk memaksimalkan laba atau keuntungan bahkan juga memaksimalkan kesejahteraan pemilik atau shareholder, melalui keputusan atau kebijakan investasi, keputusaan pendanaan, dan keputusan deviden yang tercermin dalam harga saham dipasar modal, demikian juga dilihat dari sudut pandang manajemen keuangan. Untuk mencapai tujuan tersebut, perusahaan harus inovatif dan mampu mengambil kebijakankebijakan yang tepat melalui pemanfaatan seluruh potensi sumberdaya perusahaan, maka hal tersebut mendorong perusahaan untuk meningkatkan kualitas, baik kualitas jasa maupun kualitas produknya.Hal tersebutlah
\end{abstract}

yang menjadikan suatu perusahaan retail trade atau perusahaan dagang harus mampu menjaga kinerjanya,karena dengan kinerja yang baik maka perusahaan akan dapat menunjukkan adanya kepercayaan masyarakat bahwa perusahaan retail trade tersebut dapat memenuhi kebutuhannya. Untuk itu perusahaan retail trade dapat menilai kinerjanya melalui kondisi keuangan dengan melihat laporan keuangan. . Kondisi keuangan suatu perusahaan akan dapat diketahui dari laporan keuangan yang merupakan alat yang sangat penting untuk memperoleh informasi sehubungan dengan posisi keuangan dan hasilhasil yang telah dicapai oleh perusahaan yang bersangkutan.

Dan agar dapat mengetahui perkembangan perusahaan,makasuatuperusahaansangatlahperlu untuk mengetahui kondisi keuangannya. Kondisi 
keuangan suatu perusahaan akan dapat diketahui dari laporan keuangan yang dalam analisis rasio memungkinkan manajer keuangan dan pihak yang berkepentingan untuk mengevaluasi kondisi keuangan dan akan menunjukkan kondisi sehat tidaknya suatu perusahaan. Dan dengan melihat kondisi keuangan maka dapat juga dilihat kinerja perusahaan. Karena dari menganalisis kinerja keuangan perusahaan yang berdasarkan laporan keuangan kondisi perusahaan dapat diketahui apakah perusahaan itu mengalami kemajuan atau kemunduran. Dan dari kinerja keuangan suatu perusahaan akan dapat menilai kondisi keuangannya dan aktifitasnya. Menurut Irham Fahim (2010), kinerja keuangan merupakan suatu analisis yang dilakukan untuk melihat sejauh mana suatu perusahaan telah melaksanakan dengan menggunakan aturan-aturan pelaksanaan keuangan secara baik dan benar. Maka hal itu diperlukan laporan keuangan yang diterbitkan diharapkan mencerminkan kinerja perusahaan tersebut yang sebenarnya. Hal ini disebabkan karena Laporan Keuangan merupakan suatu laporan yang berisikan informasi seputar keuangan dari sebuah organisasi atau perusahaan. Dan laporan keuangan juga untuk menilai kinerja perusahaan terlebih bagi perusahaan yang sahamnya telah tercatat dan diperdagangkan di bursa.

\section{REVIEW LITERATUR DAN HIPOTESIS}

Menurut Irham Fahmi (2010: 143), ada 5 tahap dalam menganalisa kinerja keuangan suatu perusahaan secara umum yaitu:

(1) Melakukan review terhadap data Laporan Keuangan

Review disini dilakukan dengan tujuan agar laporan keuangan yang sudah dibuat tersebut sesuai dengan penerapan kaidah - kaidah yang berlaku umum dalam akuntansi, sehingga dengan demikian hasil laporan keuangan tersebut dapat dipertanggungjawabkan.
(2) Melakukan perhitungan

Penerapan metode perhitungan disini adalah disesuaikan dengan kondisi dan permasalahan yang sedang dilakukan sehingga hasil dari perhitungan tersebut akan memberikan suatu kesimpulan sesuai dengan analisis yang diinginkan.

(3) Melakukan penafsiran (interpretation) terhadap berbagai permasalahan yang ditemukan.

Pada tahap ini analisis melihat kinerja keuangan perusahaan adalah setelah dilakukan penafsiran untuk melihat apa-apa saja permasalahan dan kendala yang dialami perbankan tersebut.

(4) Melakukan perbandingan terhadap hasil hitungan yang telah diperoleh

Dari hasil hitungan yang sudah diperoleh tersebut kemudian dilakukan perbandingan dengan hasil hitungan dari berbagai perusahaan lainnya. Metode yang paling umum dipergunakan untuk melakukan perbandingan ini ada dua yaitu:

a) Time series analysis, yaitu membandingkan secara antar waktu atau antar periode, dengan tujuan itu nantinya akan terlihat secara grafik

b) Cross sectional apporoach, yaitu melakukan perbandingan terhadap hasil hitungan rasio - rasio yang telah dilakukan antar satu perusahaan dan perusahaan lainnya dalam ruang lingkup yang sejenis yang dilakukan secara bersamaan.

Hasil penggunaan kedua metode ini diharapkan nantinya akan dapat dibuat satu kesimpulan yang menyatakan posisi perusahaan tersebut berada dalam kondisi sangat baik, baik sedang/normal, tidak baik, dan sangatlah tidak baik.

Perusahaan dalam menjalankan operasionalnya akan selalu menginginkan keuntungan (laba). Pengertian laba menurut Harahap (2010:263) yang penting dalam laporan 
keuangan antara lain: laba merupakan dasar dalam perhitungan pajak, pedoman dalam menentukan kebijakan investasi dan pengambilan keputusan, dasar dalam peramalan laba maupun kejadian ekonomi perusahaan lainnya dimasa yang akan datang, dasar dalam perhitungan penilaian prestasi atau kinerja. Pertumbuhan laba menjadi informasi yang sangat penting bagi banyak orang, yang antara lain adalah penguasa, analis keuangan, pemegang saham, ekonomi dan sebagainya. Tujuan utama pelaporan laba adalah memberikan inforrmasi yang berguna bagi mereka yang paling berkepentingan dalam laporan keuangan dan pertumbuhan laba dari tahun ke tahun juga dijadikan sebagai dasar efisiensi manajemen dan membantu meramalkan arah masa depan perusahaan atau pembagian dividen masa depan. Pada dasarnya laporan keuangan merupakan hasil dari proses akuntansi yang bisa digunakan sebagai alat untuk mengetahui aktivitas perusahaan dengan pihak-pihak yang berkepentingan dengan aktivitas tersebut. Aktivitas perusahaan tidak serta merta tanpa penilaian dan diuji, tetapi perlu diuji dan dipertanggungjawabkan. Sehingga bisa disimpulkan bahwa laporan keuangan merupakan media komunikasi dan pertanggungjawaban antara perusahaan (manajemen) dan para pemiliknya atau pihak lainnya. Ada beberapa jenis laporan keuangan dalam suatu perusahaan, yaitu sebagai berikut: Laporan Laba/Rugi, Laporan Perubahan Modal, Neraca dan Laporan Arus Kas.

Munawir (2010:5), pada umumnya laporan keuangan itu terdiri dari neraca dan perhitungan laba-rugi serta laporan perubahan ekuitas. Neraca menunjukkan/menggambarkan jumlah aset, kewajiban dan ekuitas dari suatu perusahaan pada tanggal tertentu. Sedangkan perhitungan (Laporan) laba-rugi memperlihatkan hasil-hasil yang telah dicapai oleh perusahaan serta beban yang terjadi selama periode tertentu, dan laporan perubahan ekuitas menunjukkan sumber dan penggunaan atau alasan-alasan yang menyebabkan perubahan ekuitas perusahaan. Laporan keuangan dapat dengan jelas memperlihatkan gambaran kondisi keuangan dari perusahaan. Laporan keuangan yang merupakan hasil dari kegiatan operasi normal perusahaan akan memberikan informasi keuangan yang berguna bagi entitas-entitas di dalam perusahaan itu sendiri maupun entitas- entitas lain diluar perusahaan.

Laporan keuangan yang disajikan oleh perusahaan dalam beberapa kurun waktu dapat digunakan untuk memprediksi laba atau dividen di waktu yang akan datang. Dari sudut pandang investor analis laporan keuangan dapat digunakan sebagai alat prediksi prospek masa depan perusahaan tersebut. Sementara itu dari sudut pandang manajemen selain alat prediksi antisipasi masa depan, juga sebagai dasar untuk perencanaan tindakan terhadap faktor-faktor kunci yang sering mempengaruhi peristiwa pada masa lalu sebagai pedoman kedepan.

Rasio keuangan dapat juga sebagai pembanding posisi perusahaan dengan pesaing, untuk kebijakan keuangan perusahaan ke depan Ada dua cara dalam menilai rasio keuangan agar lebih berarti: Menilai rasio keuangan antar waktu (sebaiknya waktu yang cukup lama, misal 5 tahun agar dapat diketahui arah pergerakannya) serta membandingkan rasio keuangan perusahaan dengan rasio industri. Penilaian ini akan dapat menilai perusahaan apakah lebih baik atau tidak dibandingkan dengan pesaing kita.

Dalam menjalankan usaha, pemilik dan manajemen harus mengetahui berapa uang yang keluar dan masuk ke perusahaan dalam periode tertentu. Uang yang keluar juga harus dirinci penggunaan dan jumlahnya. Demikian pula dengan jenis pendapatan yang diperolehnya. Catatan keuangan yang terjadi selama periode tertentu dibuat dalam bentuk laporan keuangan.

Laporan keuangan dibuat sesuai dengan kaidah keuangan yang berlaku agar mampu menunjukkan kondisi dan posisi keuangan yang 
sesungguhnya. Laporan keuangan juga harus dibuat sesuai dengan aturan yang berlaku sehingga mudah dibaca, dipahami, dan dimengerti oleh berbagai pihak yang berkepentingan, terutama pihak pemilik usaha dan manajemen. Artinya pula, dengan laporan keuangan, setiap orang dapat memahami kondisi dan posisi keuangan perusahaan yang terjadi saat ini, Kasmir (2014: $3)$.

Untuk mampu mengerti arti laporan keuangan, perlu dilakukannya analisis terlebih dahulu dengan berbagai alat analisis yang biasa digunakan. Salah satu alat analisis tersebut disebut sebagai analisis laporan keuangan. Dengan menggunakan analisis laporan keuangan, terutama bagi pemilik usaha dan manajemen, dapat diketahui berbagai hal yang berkaitan dengan keuangan dan kemajuan perusahaan. Pemilik usaha dapat mengetahui kondisi keuangan perusahaan dan menilai kinerja manajemen sekarang, apakah mencapai target yang telah ditetapkan atau tidak. Bagi pihak manajemen, laporan keuangan merupakan cerminan kinerja yang telah dilakukan selama ini. Hasil dari analisis keuangan adalah berupa laporan keuangan, laporan keuangan dapat memberikan gambaran bagi pihak manajemen untuk dipergunakan dalam menentukan arah tujuan perusahaan kedepan dengan kata lain bisa digunakan sebagai acuan dalam pengambilan keputusan.

Menurut Kasmir (2014:128) analisis rasio keuangan dibagi atas 4 rasio keuangan yaitu

\section{a. Rasio likuiditas ( Liquidity Ratio )}

Merupakan rasio yang menggambarkan kemampuan perusahaan dalam memenuhi kewajiban (utang) jangka pendek. Artinya apabila perusahaan ditagih, perusahaan akan mampu untuk memenuhi utang tersebut, terutama utang yang sudah jatuh tempo. Dengan kata lain, rasio likuiditas berfungsi untuk menunjukkan atau mengukur kemampuan perusahaan dalam memenuhi kewajibannya yang sudah jatuh tempo, baik kewajiban kepada pihak luar perusahaan (likuiditas badan usaha) maupun didalam perusahaan (likuiditas perusahaan).

\section{Jenis-jenis Rasio Likuiditas}

Dalam praktiknya, untuk mengukur rasio keuangan secara lengkap, dapat menggunakan jenis-jenis rasio likuiditas yang ada. Jenis-jenis rasio likuiditas yang dapat digunakan perusahaan untuk mengukur kemampuan, yaitu :

\section{Rasio lancar ( current ratio )}

Rasio lancar atau (current ratio) merupakan rasio untuk mengukur kemampuan perusahaan dalam membayar kewajiban jangka pendek atau utang yang segera jatuh tempo pada saat ditagih secara keseluruhan. Dengan kata lain, seberapa banyak aktiva lancar yang tersedia untuk menutupi kewajiban jangka pendek yang segera jatuh tempo.

\section{Current ratio $=($ Aktiva Lancar $/$ hutang lancar)}

\section{Rasio Cepat (Quick Ratio)}

Rasio cepat (Quick Ratio) atau rasio sangat lancar atau acid test ratio merupakan rasio yang menunjukkan kemampuan perusahaan dalam memenuhi atau membayar kewajiban atau utang lancar (utang jangka pendek) dengan aktiva lancar tanpa memperhitungkan nilai sediaan (inventory). Artinya nilai sediaan kita abaikan, dengan cara dikurangi dari nilai total aktiva lancar.

\section{Quick Ratio $=(($ Aktiva Lancar - Persediaan) / Hutang lancar))}

\section{Rasio Kas (Cash Ratio)}

Rasio kas atau cash ratio merupakan alat yang digunakan untuk mengukur seberapa besar uang kas yang tersedia untuk membayar utang. Ketersediaan uang kas dapat ditunjukkan dari tersedianya dana kas atau yang setara dengan kas seperti rekening giro atau tabungan di 
bank (yang dapat ditarik setiap saat).

Cash Ratio $=(($ kas + bank $) /$ Hutang lancar $))$

\section{Rasio Perputaran Kas (Cash turn over)}

Rasio perputaran kas (Cash turn over) berfungsi untuk mengukur tingkat kecukupan modal kerja perusahaan yang dibutuhkan untuk membayar tagihan dan membiayai penjualan. Artinya rasio ini digunakan untuk mengukur tingkat ketersediaan kas untuk membayar tagihan (utang) dan biaya-biaya yang berkaitan dengan penjualan. Hasil perhitungan rasio perputaran kas dapat diartikan sebagai berikut:

a) Apabila rasio perputaran kas tinggi ini berarti, ketidakmampuan perusahaan dalam membayar tagihannya.

b) Sebaliknya apabila rasio perputaran kas rendah, dapat diartikan kas yang tertanam pada aktiva yang sulit dicairkan dalam waktu singkat sehingga prusahaan harus bekerja keras dengan kas yang lebih sedikit.

\section{Rasio Perputaran kas $=$ Penjualan bersih}

\section{Modal kerja bersih}

\section{Hasil pengukuran Kinerja}

Perusahaan mengetahui baik atau tidaknya kondisi keuangan perusahaan dilihat dari standar industri yang ditetapkan dalam setiap jenis rasio keuangan yang ada, dari pengukuran Rasio dapat melihat kondisi posisi keuangan perusahaan seperti yang terlihat dalam tabel Berikut ini :

\section{Hasil 1}

Pengukuran Standar Industri Perusahaan

\begin{tabular}{|l|l|l|}
\hline No & \multicolumn{1}{|c|}{ Jenis Rasio } & \multicolumn{1}{|c|}{$\begin{array}{c}\text { Standard } \\
\text { Industri }\end{array}$} \\
\hline 1 & Current Ratio & $2 \mathrm{kali}(200 \%)$ \\
\hline 2 & Ouick Ratio & $1,5 \mathrm{kali}(150 \%)$ \\
\hline 3 & Cash Ratio & $50 \%$ \\
\hline 4 & Cash turn over & $10 \%$ \\
\hline 5 & $\begin{array}{l}\text { Inventory to net } \\
\text { working capital }\end{array}$ & $12 \%$ \\
\hline
\end{tabular}

Sumber : Analisis laporan keuangan , Kasmir ( 2014 )

\section{b. Rasio Solvabilitas (Levarage Ratio)}

Merupakan rasio yang digunakan mengukur sejauh mana aktiva perusahaan dibiayai dengan utang. Artinya berapa besar beban utang yang ditanggung perusahaan dibandingkan dengan aktivanya. Dalam arti luas dikatakan bahwa rasio solvabilitas digunakan untuk mengukur kemampuan perusahaan untuk membayar seluruh kewajibannya, baik jangka pendek maupun jangka panjang apabila perusahaan dibubarkan (dilikuidasi).

\section{Jenis-jenis Rasio Solvabilitas}

Biasanya penggunaan rasio solvabilitas atau lavarage disesuaikan dengan tujuan perusahaan. Artinya perusahaan dapat menggunakan rasio levarage secara keseluruhan atau sebagian dari masing-masing jenis rasio solvabilitas yang ada. Dalam praktiknya, terdapat beberapa jenis rasio solvabilitas yang sering digunakan perusahaan. Adapun jenis-jenis rasio yang ada dalam rasio solvabilitas antara lain:

\section{Debt to Asset Ratio (Debt Ratio)}

Merupakan ratio utang yang digunakan untuk mengukur perbandingan antara total utang dengan total aktiva. Dengan kata lain, seberapa besar aktiva perusahaan dibiayai oleh utang atau seberapa besar utang perusahaan berpengaruh terhadap pengelolaan aktiva.

\section{Debt to Asset ratio $=($ Total utang $/$ Total aktiva $)$}

\section{Debt to Equity Ratio}

Merupakan rasio yang digunakan untuk menilai utang dengan ekuitas. Rasio ini dicari dengan cara membandingkan antara seluruh utang, termaksud utang lancar dengan seluruh ekuitas. Rasio ini berguna untuk mengetahui jumlah dana yang disediakan peminjam (kreditor) dengan pemilik perusahaan. Rumus untuk mencari Debt to Eguity Ratio dapat digunakan perbandingan antara total utang dengan total ekuitas sebagai 
berikut :

Debt to Eguity Ratio = $($ Total utang $/$ Ekuitas $)$

\section{Long term Debt to Equity Ratio (LTDtER)}

Merupakan rasio antara utang jangka panjang dengan model sendiri. Tujuannya adalah untuk mengukur berapa bagian dari setiap rupiah modal sendiri yang dijadikan jaminan utang jangka panjang dengan cara membandingkan antara utang jangka panjang dengan modal sendiri yang disediakan oleh perusahaan.

\section{LTDtER = ( Total utang jangka panjang / Total Equity)}

\section{Times Interest Earned}

Merupakan rasio untuk mencari jumlah kali perolehan bunga. Rasio ini diartikan sebagai kemampan perusahaan untuk membayar biaya bunga, sama seperti Coverage Ratio. Jumlah kali perolehan bunga atau times interest ratio merupakan rasio untuk mengkur sejauh mana pendapatan dapat menurun tanpa membuat perusahaan merasa malu karena tidak mampu membayar biaya bunga tahunannya. Apabila perusahaan tidak mampu membayar bunga, dalam jangka panjang menghilangkan kepercayaan dari para kreditor. Untuk mengukur rasio ini, digunakan perbandingan antara laba sebelum bunga dan pajak dibandingkan dengan biaya bunga yang dikeluarkan. Dengan demikian kemampan perusahaan untuk membayar bunga pinjamin tidak dipengaruhi oleh pajak

Times interest earned $=$ Earning before intereset and tax ( EBIT)

Biaya bunga

\section{Hasil pengukuran Kinerja}

Perusahaan mengetahui baik atau tidaknya kondisi keuangan perusahaan dilihat dari standard Industri yang ditetapkan dalam setiap jenis rasio keuangan yang ada, dari pengukuran Rasio kita dapat melihat kondisi posisi keuangan perusahaan seperti yang terlihat dalam tabel Berikut ini:
Tabel 2

Kinerja Perusahaan

\begin{tabular}{|l|l|l|}
\hline No & \multicolumn{1}{|c|}{ Jenis Rasio } & \multicolumn{1}{c|}{$\begin{array}{c}\text { Standard } \\
\text { Industri }\end{array}$} \\
\hline 1 & Debt to asset ratio & $35 \% \%$ \\
\hline 2 & Debt to equity & $90 \%$ \\
3 & $\begin{array}{l}\text { Long teerm debt to equity } \\
\text { ratio (LTDtER) }\end{array}$ & $10 \mathrm{kali}$ \\
\hline 4 & Times interes earned & $10 \mathrm{kal}$ \\
\hline 5 & Fixed charge coverage & $10 \mathrm{kali}$ \\
\hline
\end{tabular}

Sumber : Analisis Laporan Keuangan, Kasmir (2014)

\section{c. Rasio Aktivitas (Activity ratio)}

Merupakan rasio yang digunakan untuk mengukur efektivitas perusahaan dalam menggunakan aktiva yang dimilikinya. Atau dapat pula dikatakan rasio ini digunakan untuk mengukur tingkat efisiensi (efektivitas) pemanfaatan sumber daya perusahaan. Efisiensi yang dilakukan misalnya dibidang penjualan, sediaan penagihan piutang dan efisiensi dibidang lainnya. Rasio aktivitas juga digunakan untuk menilai kemampuan perusahaan dalam melaksanaan aktivitas sehari-hari. Dari hasil pengukuran dengan rasio aktivitas akan terlihat apakah persahaan lebih efisien dan efektif dalam mengelola aset yang dimilikinya atau mungkin justru sebaliknya.

\section{Jenis-Jenis Rasio Aktivitas}

Rasio Aktivitas yang dapat digunakan manajemen untuk mengambil keputusan terdiri dari beberapa jenis. Penggunaan rasio yang diinginkan sangat tergantung dari keinginan manajemen perusahaan. Artinya lengkap tidaknya rasio aktivitas yang akan digunakan tergantung dari kebutuhan dan tujuan yang ingin dicapai pihak manajemen perusahaan tersebut. Secara umum apabila seluruh rasio aktivitas yang ada digunakan akan mampu memperlihatkan efektivitas perusahaan secara maksimal, jika dibandingkan dengan penggunaan hanya sebagian saja. Berikut ini beberapa jenis-jenis rasio aktivitas yang dirangkum dari beberapa ahli keuangan, yaitu : 
1. Perputaran Piutang (Receivable turn over) Perputaran piutang merupakan rasio yang digunakan untuk mengukur berama lama penagihan piutang selama satu periode atau berapa kali dana yang ditanam dalam piutang ini berputar dalam dalam satu periode. Semakin tinggi rasio menunjukkan bahwa modal kerja yang ditanamkan dalam piutang semakin rendah (bandingkan dengan rasio tahun sebelumnya) dan tentunya kondisi ini bagi perusahaan semakin baik. Sebaliknya jika rasio semakin rendah ada over investment dalam piutang. hal yang jelas adalah rasio perputaran piutang member pemahaman tentang kualitas piutang dan kesuksesan penagihan piutang. Cara untuk mencari rasio ini adalah dengan membandingkan antara penjualan kredit dengan rata-rata piutang.

Perputaran piutang $=($ Penjualan kredit $/$ Rata-rata Piutang)

2. Perputaran Sediaan (Inventory Turn Over) Perputaran sediaan merupakan rasio yang digunakan untuk mengukur berapa kali dana yang ditanam dalam sediaan (inventory) ini berputar dalam satu periode. Cara menghitung rasio perputaran sediaan dilakukan dengan dua cara yaitu: pertama, membandingkan antara harga pokok barang yang dijual dengan nilai sediaan dan kedua, membandingkan antara penjualan nilai sediaan. Apabila rasio yang diperoleh tinggi, ini menunjukkan perusahaan bekerja secara efisien dan likuid persediaan semakin baik.

Inventory turn over $=$ Harga pokok barang yang dijual

Persediaan

3. Perputaran Modal Kerja (Working Capital Turn Over)

Perputaran modal kerja atau working capital turn over merupakan salah satu rasio untuk mengukur atau menilai keefektifan modal kerja perusahaan selama periode tertentu. Artinya seberapa banyak modal kerja berputar selama satu periode atau dalam suatu periode. Untuk mengukur rasio ini, kita membandingkan antara penjualan dengan modal kerja atau dengan modal kerja ratarata. Dari hasil penilaian, apabila perputaran modal kerja yang rendah, dapat diartikan perusahaan sedang kelebihan modal kerja. Hal ini mungkin disebabkan karena rendahnya perputaran persediaan atau piutang atau saldo kas yang terlala besar. Cara untuk mencari perputaran modal kerja adalah sebagai berikut:

Perputaran modal kerja $=$ Penjualan bersih

Modal kerja rata-rata

\section{Fixed Assets Turn Over}

Merupakan rasio yang digunakan untuk mengukur berapa kali dana yang ditanamkan dalamaktiva tetap berputar dalam satu periode. Atau dengan kata lain, untuk mengukur apakah perusahaan sudah menggunakan kapasitas aktiva tetap sepenuhnya tau belum. Untuk mencari rasio ini, caranya adalah membandingkan antara penjualan bersih dengan aktiva tetap dalam suatu periode.

Fixed Assets turn over $=($ Penjualan $/$ Total Aktiva Tetap)

\section{Total Assets Turn Over}

Merupakan rasio yang digunakan untuk mengukur perputaran semua aktiva yang dimiliki perusahaan dan mengukur berapa jumlah penjualan yang diperoleh dari tiap rupiah aktiva.

Total asset turn over $=($ Penjualan $/$ Total Aktiva )

\section{Hasil pengukuran kinerja}

Perusahaan mengetahui baik atau tidaknya kondisi keuangan perusahaan dilihat dari standard Industri yang ditetapkan dalam setiap jenis rasio 
keuangan yang ada, dari pengukuran Rasio kita dapat melihat kondisi posisi keuangan perusahaan seperti yang terlihat dalam table Berikut ini

Tabel 3

Rasio-rasio Keuangan Perusahaan

\begin{tabular}{|c|l|l|}
\hline No & \multicolumn{1}{|c|}{ Jenis Rasio } & $\begin{array}{c}\text { Standard } \\
\text { Industri }\end{array}$ \\
\hline 1 & Receivable turn over & $15 \mathrm{kali}$ \\
\hline 2 & Inventory turn Over & $20 \mathrm{kali}$ \\
\hline 3 & Working capital turn over & $6 \mathrm{kali}$ \\
\hline 4 & Fixed asset turn over & $5 \mathrm{kal}$ \\
\hline 5 & Total asset turn over & $2 \mathrm{kali}$ \\
\hline
\end{tabular}

Sumber: Analisis Laporan keuangan, Kasmir (2014)

\section{d. Rasio Profitabilitas}

Merupakan rasio untuk menilai kemampuan perusahaan dalam mencari keuntungan. Rasio ini juga memberikan ukuran tingkat efektivitas manajemen suatu perusahaan. Hal ini ditunjukkan oleh laba yang dihasilkan dari penjualan dan pendapatan investasi. Intinya adalah penggunaan rasio ini menujukkan efisiensi perusahaan. Penggunaan rasio profitabilitas dapat dilakukan dengan menggunakan perbandingan antara berbagai komponen yang ada dalam laporan keuangan, terutama laporan keuangan neraca dan laba rugi. Tujuannya adalah agar terlihat perkembangan perusahaan dalam rentang waktuu tertentu, baik penurunan atau kenaikan sekaligus mencari penyebab perubahan tersebut.

\section{Jenis-jenis Rasio Profitabilitas}

Sesuai dengan tujuan yang hendak dicapai, terdapat beberapa jenis rasio profitabilitas yang digunakan. Masing-masing jenis rasio profitabilitas digunakan untuk menilai serta mengukur posisi keuangan perusahaan dalam suatu periode tertentu atau untuk beberapa periode. Penggunaan seluruh atau sebagian rasio profitabilitas tergantung dari kebijakan manajemen. Jelasnya, semakin lengkap jenis rasio yang digunakan semakin sempurna hasil yang akan dicapai. artinya pengetahuan tentang kondisi dan posisi profitabilitas perusahaan dapat diketahui secara sempurna.

\section{Profit Margin on Sales}

Profit margin on sales atau ratio profit margin atau margin laba atas penjualan merupakan salah satu rasio yang digunakan untuk mengukur margin laba atas penjualan. Cara pengukuran rasio ini adalah dengan membandingkan laba bersih setelah pajak dengan penjualan bersih. rasio ini juga dikenal dengan nama profit margin. Terdapat dua rumus untk mencari profit margin, yaitu sebagai berikut:

a. Untuk margin laba kotor dengan rumus:

Profit margin $=$ Penjualan bersih - harga pokok penjualan

$$
\text { Sales }
$$

Margin laba kotor menunjukkan laba yang relative terhadap perusahaan, dengan cara penjualan bersih dikurangi harga pokok penjualan. Rasio ini merupakan cara untuk penetapan harga pokok penjualan.

Untuk margin laba bersih dengan rumus:

Net Profit Margin = Earning After interest and Tax (EAIT)

\section{sales}

Margin laba bersih merupakan ukuran keuntungan dengan membandingkan antara laba setelah bunga dan pajak dibandingkan dengan penjualan. Rasio ini menunjukkan pendapatan bersih perusahaan atas penjualan.

\section{Return On Invesment (ROI)}

Return On invesment atau return on asset menunjukan kemampuan perusahaan menghasilkan laba dari aktiva yang dipergunakaan. Dengan mengetahui rasio ini, akan dapat diketahui apakah perusahan efesien dalam memanfaatkan aktivanya dalam kegiatan operasional perusahan rasio ini juga memberikan ukursn yang lebih bbaik atas profitabilitas perusahaan karena Return on Eguity menunjukan efektivitas manajemen dalam menggunakan aktiva untuk memperoleh pendapatan

ROI = (( Laba setelah pajak / Total Assets x $100 \%))$ 
3. Return on Equity (ROE)

Return on Equity (ROE) adalah rasio profitabilitas yang membandingkan antar laba bersih (net profit) perusahaan dengan aset bersihnya (ekuitas atau modal). Rasio ini mengukur berapa banyak keuntungan yang dihasilkan oleh Perusahaan dibandingkan dengan modal yang disetor oleh Pemegang Saham

Return on Equity = (Laba bersih / Ekuitas)

\section{Laba Per Lembar Saham Biasa (Earning per Share of Common Stock)}

Rasio laba per lembar saham atau disebut juga rasio nilai buku merupakan rasio untuk mengukur keberhasilan manajemen dalam mencapai keuntungan bagi pemegang saham. Rasio yang rendah berarti manajemen belum berhasil untuk memuaskan pemegang saham, sebaliknya dengan rasio yang tinggi, kesejahteraan pemegang saham meningkat. Dengan pengertian lain, tingkat pengembalian yang tinggi. Keuntungan bagi pemegang saham adalah jumlah keuntungan setelah dipotong pajak. Keuntungan yang tersedia bagi pemegang saham biasa adalah jumlah keuntungan dikurangi pajak, deviden dan dikurangi hak-hak lain untuk pemegang saham prioritas.

Laba per Lembar Saham = Laba saham biasa

Saham biasa yang beredar

\section{Hasil pengukuran kinerja}

Perusahaan mengetahui baik atau tidaknya kondisi keuangan perusahaan dilihat dari standard Industri yang ditetapkan dalam setiap jenis rasio keuangan yang ada, dari pengukuran Rasio kita dapat melihat kondisi posisi keuangan perusahaan seperti yang terlihat dalam tabel Berikut ini :
Tabel 4

Kondisi Keaungan Perusahaan

\begin{tabular}{|c|l|l|}
\hline No & \multicolumn{1}{|c|}{ Jenis Rasio } & \multicolumn{1}{c|}{$\begin{array}{c}\text { Standard } \\
\text { Industri }\end{array}$} \\
\hline 1 & Net Profit margin & $20 \%$ \\
\hline 2 & Return on investment & $30 \%$ \\
\hline 3 & Return on Equity & $40 \%$ \\
\hline 4 & Fixed asset turn over & $5 \mathrm{kali}$ \\
\hline 5 & Total asset turn over & $2 \mathrm{kall}$ \\
\hline
\end{tabular}

Sumber : Analisis Laporan Keuangan , Kasmir (2014)

\section{METODE PENELITIAN}

Teknik pengumpulan data yang digunakan dalam penelitian ini adalah teknik dokumentasi yaitu dengan cara mengumpulkan data sekunder yang diperoleh dari berbagai sumber, baik secara pribadi maupun kelembagaan yang kemudian di kembangkan untuk kepentingan penelitian. Dalam penelitian ini penulis mengumpulkan data sekunder berupa laporan keuangan tahunan perusahaan Retail trade yang telah terdaftar di Bursa Efek Indonesia melalui situs resmi BEI www.idx.co.id . Sedangkan teknik analisis data ada dua yaitu: Analisis Kualitatif adalah data yang didapatkan akan dianalisis dengan penilaian teoritis dan logis sesuai dengan pembuktian secara kuantitatifnya. Serta Analisis Kuantitatif adalah data yang dianalisis secara pembuktian angka angka sesuai dengan data yang di dapat dalam penelitian.

\section{HASIL PENELITIAN DAN PEMBAHASAN}

Perusahaan retail trade yang terdaftar di Bursa Efek Indonesia di tahun 2015. Menunjukkan bahwa rata rata perusahaan mempunyai nilai Rasio lancar yang menunjukkan bahwa setiap Rp 1,00 Hutang Lancar dapat dijamin dengan Rp. 4,50 Aktiva Lancar. Jadi dapat disimpulkan jika rata-rata industri perusahaan adalah dua kali keadaan perusahaan berada dalam kondisi baik mengingat rasionya diatas rata-rata industri. 
Rata-rata industri untuk Quick ratio adalah 1,5 kali maka keadaan perusahaan itu kondisi lebih baik. Quick Ratio pada rata rata perusahaan retail trade untuk tahun 2015 diatas dari rata-rata industri perusahaan sehingga keadaan perusahaan membaik.

Rata-rata standar industri untuk Debt to Asset Ratio menujukkan 35\% rata-rata industri. Apabila dibawah rata-rata industri akan sulit bagi perusahaan untuk memperoleh pinjaman. Pada tahun 2015, rasio ini menunjukan bahwa 24\% pendanaan perusahaan dibiayai dengan hutang, artinya bahwa setiap Rp 100,00 atau 1,00 aktiva pendanaan perusahaan, $\mathrm{Rp} 24,00$ dibiayai dengan utang dan Rp 76,00 disediakan oleh pemegang hutang. kondisi tersebut menunjukkan perusahaan dibiayai hampir separuhnya utang. apabila perusahaan bermaksud menambahkan utang, perusahaan perlu menambahkan dulu ekuitasnya.

Nilai rasio DER sebesar 30\%, ini berarti setiap Rp.1,0 ekuitas perusahaan dibiayai oleh hutang sebesar Rp. 0,29. Pada tahun 2015 rata rata nilai rasio DER sebesar 51\% ini berarti setiap Rp. 1,0 ekuitas perusahaan dibiayai oleh hutang sebesar Rp. 0,51. penurunan nilai rasio ini disebabkan oleh semakin menurunnya jumlah Hutang disertai dengan semakin meningkatnya modal sendiri perusahaan. Peningkatan modal sendiri berasal dari cabang dan laba tahun berjalan yang cukup besar. Jadi dapat disimpulkan untuk mengukur kinerjanya sesuai dengan standar pengukuran perusahaan rata-rata industri dibawah $80 \%$, perusahaan masih dianggap kurang baik karena berada dibawah rata- rata industri perusahaan.

Inventory Turn over atau perputaran sediaan ini digunakan untuk mengukur berapa kali dana yang ditanam dalam persediaan (inventory) ini berputar dalam suatu periode. Untuk menghitung rasio ini dapat dilakukan dengan dua cara melalui membandingkan antara harga pokok barang yang dijual dengan nilai sediaan dan dapat melalui membandingkan antara penjualan dan persediaan dalam hal ini digunakan dengan cara membandingkan antar penjualan dan persediaan. Pada tahun 2015 perputaran persediaan meningkat, ini diakibatkan oleh nilai persediaan semakin meningkat akan tetapi nilai penjualan semakin menurun. Apabila rasio yang diperoleh semakin tinggi, ini menujukkan perusahaan bekerja secara efisien dan likuid perusahaan semakin baik, tetapi apabila rasionya semakin rendah perusahaan bekerja secara tidak efisien atau tidak produktif dan banyak barang sediaan yang semakin menumpuk.

Rasio total asset turn over ini menggambarkan sejauh mana dana yang ditanamkan dalam aktiva berputar selama tahun berjalan atau untuk mengukur perputaran semua aktiva yang dimiliki perusahaan dan mengukur berapa jumlah penjualan yang diperoleh dari tiap rupiah aktiva. Dari hasil perhitungan perputaran aktiva untuk tahun 2015 terakhir terlihat bahwa rata-rata perusahaan retail trade perputarannya menurun. Perputaran aktiva pada tahun 2015 menunjukkan nilai 0,0006 artinya bahwa setiap Rp. 1,0 aktiva rata-rata berputar selama setahun menghasilkan Rp. 0,0006. Hal ini dikarenakan peningkatan nilai aktiva perusahaan sedangkan penjualan yang dihasilkan belum dapat ditingkatkan. Atau dengan kata lain perusahaan diharapkan dapat meningkatkan lagi penjualannya atau mengurangi sebagian aktiva yang kurang produktif.

Rasio ini digunakan untuk mengukur berapa kali dana yang ditanamkan pada aktiva tetap berputar dalam satu periode. Kondisi perusahaan dikatakan baik apabila jumlah aktiva tetapnya bertambah dalam tiap tahunnya, dalam perhitungan analisis rasio Fixed Assets Turn Over dapat dilihat pada tahun 2015 sebesar 0,00055.

Perhitungan ROA pada tahun 2015 pada rata rata perusahaan retail trade ini sebesar $5,30 \%$ dimana tingkat pengembalian asset yang diperolehnya tiap tahunnya cukup baik. Rata- 
rata industri untuk return on Asset adalah 30\% $(3.0 \%)$ berarti margin laba perusahaan untuk tahun tersebut cukup baik, dan bisa dilihat hal ini bisa meningkatkan kinerja keuangan, akan tetapi apabila ROA nya dibawah rata-rata standar industri itu menujukkan ketidakmampuan manajemen untuk memperoleh ROA. Rendahnya margin laba karena rendahnya perputaran Aktiva.

\section{KESIMPULAN DAN SARAN}

\section{Kesimpulan}

Pada rasio Likuiditas, posisi keuangan dilihat dari tahun 2015 secara keseluruhan rasio pada rata rata perusahaan retail trade, menunjukkan kondisi keuangan dalam keadaan baik.

Pada Rasio Solvabilitas, analisis ini membandingkan antara total hutang dan aktiva dan membandingan total hutang dan ekuitas. Setelah dilihat dari perhitungan tersebut dapat ditarik kesimpulan bahwa kondisi rata rata perusahaan retail trade tersebut dikatakan ada peningkatan di perusahaan retail trade. Sebagian nilai rasio perusahaan retail trade ada yang menurun hal ini menunjukkan perusahaan dibiayai hampir sebagian hutang. Apabila perusahaan ingin menambahkan utangnya perusahaan terlebih dulu menambahkan ekuitasnya.

Pada Rasio Profitabilitas, Dari perhitungan analisis ROA yang dilakukan pada rata rata Perusahaan retail trade tersebut dapat ditarik kesimpulan bahwa rata-rata industry untuk return on Asset adalah $30 \%$ (3.0\%) berarti margin laba perusahaan untuk tahun tersebut cukup baik, dan bisa dilihat hal ini bisa meningkatkan kinerja keuangan, akan tetapi apabila ROA nya dibawah rata-rata standar industri itu menujukkan ketidakmampuan manajemen untuk memperoleh ROA. Rendahnya margin laba karena rendahnya perputaran Aktiva. Apabila mengalami penurunan dari nilai rasio sebelumnya, Rendahnya margin laba karena rendahnya perputaran Aktiva. Hal ini mungkin disebabkan oleh persentasi kenaikan laba bersih lebih besar daripada prosentase kenaikan total aktiva.

Pada Rasio Aktivitas, analisis ini dapat di simpulkan untuk rata rata perusahaan retail trade adalah peningkatan nilai aktiva perusahaan sedangkan penjualan yang dihasilkan belum dapat ditingkatkan. Atau dengan kata lain perusahaan diharapkan dapat meningkatkan lagi penjualannya atau mengurangi sebagian aktiva yang kurang produktif. Hal lainnya juga nilai persediaan semakin meningkat akan tetapi nilai penjualan semakin menurun. Apabila rasio yang diperoleh semakin tinggi, ini menujukkan perusahaan bekerja secara efisien dan likuid perusahaan semakin baik. tetapi apabila rasionya semakin rendah perusahaan bekerja secara tidak efisien atau tidak produktif dan banyak barang sediaan yang semakin menumpuk.

\section{Saran}

Perusahaan retail trade secara rata rata harus mempertahankan dan memperbaiki kinerja keuangan perusahaan, terutama yang berkaitan dengan perolehan laba.

Setelah mengetahui posisi keuangan, rata rata perusahaan retail trade perlu melakukan koreksi dan perbaikan kinerja keuangan perusahaan, mengoreksi penyebab menurunnya rasio keuangan sehingga dapat menghindari masalah kesulitan keuangan guna kelangsungan aktivitas perusahaan di masa yang akan datang. 


\section{DAFTAR PUSTAKA}

Fahmi, Irham, 2010. Analisis Laporan Keuangan, Edisi Pertama. Alfabeta. Bandung.

Hery. 2015. Analisis Laporan Keuangan, PT Buku Seru. Cet 1. Yogyakarta.

Kasmir. 2014. Analisis Laporan Keuangan, Edisi Pertama (Revisi). PT RajaGrafindo Persada. Jakarta.
Kuncoro, Mudrajad. 2011. Metode Kuantitatif, Edisi Empat. Unit Penerbit dan Percetakan Sekolah Tinggi Ilmu Manajemen. Yogyakarta

Munawir. 2010. Analisa Laporan Keuangan, Edisi Keempat. Liberty. Yogyakarta.

Pura, Rahman. 2013. Pengantar Akuntansi 1: Pendekatan Siklus Akuntansi, Edisi Pertama. Erlangga. Jakarta. 